\title{
JOURNAL.RU
}

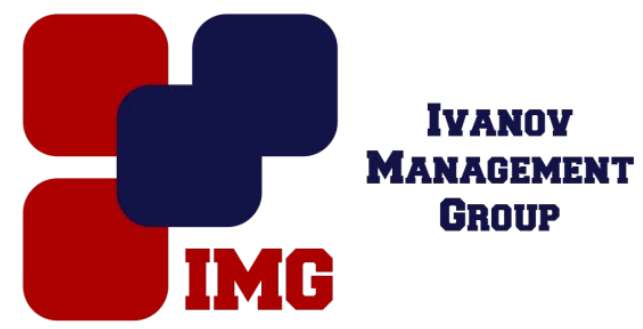

Попова М.А., Баева Н.А. Российский Университет Правосудия Воронеж, Россия

doi: 10.18411/lj-28-02-2017-2-03

idsp 000001:lj-28-02-2017-2-03

\section{Некоторые особенности формирования коллегии присяжных заседателей}

\section{Аннотация}

Статья посвящена вопросам особенности формирования коллегии присяжных заседателей в соответствии с действующим в Российской Федерации уголовно-процессуальным законодательством.

Ключевые слова: коллегия присяжные заседатели, формирование коллегии присяжных заседателей, суд присяжных.

\section{Abstract}

\section{Features of formation of the jury}

The article is devoted to peculiarities of formation of the jury in accordance with the current Russian Federation criminal procedure legislation.

Key words: panel of jurors, the formation of the jury, the jury.

\section{Актуальность проблемы}

В современной научной литературе часто высказываются мнения ученых, относительно реформирования института присяжных заседателей. В частности, предлагается скорректировать процесс формирования коллегии присяжных заседателей, выдвигаются предложения как по существенному упрощению механизма формирования коллегии присяжных заседателей, так и по введению дополнительных механизмов проверки добросовестности и личных данных будущих присяжных заседателей (что естественно приведет к услужению процесса формирования коллегии присяжных заседателей). Таким образом сегодня необходимо провести анализ особенностей формирования коллегии присяжных заседателей и высказать свои предположения относительно необходимости формирования данного правового института.

Как показывает анализ уголовно-процессуального законодательства, рассмотрение уголовного дела с участием присяжных заседателей в целом построено на основе общего порядка уголовного судопроизводства, однако при этом имеет достаточно большое количество особенностей. Судебный процесс с участием присяжных заседателей условно можно разделить на несколько стадий: стадия предварительного слушания по уголовному делу; стадия подготовки к 
рассмотрению уголовного дела; стадию судебного следствия по уголовному делу; стадия прения сторон по уголовному делу; стадия реплики и последнего слово подсудимого по уголовному делу; стадия постановки вопросов, подлежащих разрешению присяжными заседателями;стадия оглашения напутственного слова председательствующего; стадия совещание присяжных; вынесение и провозглашение вердикта по уголовному делу; стадия обсуждения последствий вердикта для уголовного дела; стадия постановления приговора по уголовному делу.

В стадии предварительного слушания по уголовному делу, председательствующим определяются основания инициации судебного процесса с участием присяжных заседателей. При этом судья, перед назначением предварительного дела к слушанию, обязательно должен проверить выполнение следователем требований ст. 217, 218 УПК РФ. Исходя из содержания данных норм, следователь осуществляющий предварительное расследование по уголовному делу в обязательном порядке должен информировать обвиняемого (в частности разъяснить обвиняемому его право) на рассмотрение уголовного дела судом присяжных, его общие права как субъекта уголовного судопроизводства осуществляемого в форме суда присяжных, порядок обжалования судебного решения вынесенного судом присяжных, а также непосредственно выяснить желание обвиняемого воспользоваться судом присяжных.

На основании проведенного предварительного слушания и подтверждения подсудимым своего желания воспользоваться правом на суд присяжных, судья выносит постановление о назначении уголовного дела к слушанию. В данном постановлении в обязательном порядке указывается количество присяжных заседателей, которых необходимо вызвать в судебное заседание (не менее двадцати). Также в данном постановлении отражается в каком режиме будет проходить судебное заседание по уголовному делу - открытом, закрытом, или частично закрытом.

После того, как судебное заседание с участием присяжных заседателей было назначено, помощник судьи (либо секретарь) производит случайный отбор из находящихся в каждом суде субъекта Российской Федерации и каждом окружном (флотском) военном суде общего и запасного списков кандидатов в присяжные заседатели посредством случайной выборки, а также проверяет обстоятельства, которые препятствуют привлечению того или иного лица в качестве присяжного заседателя (ч. 1 и 2 ст. 326 УПК РФ).После того, как секретарь или помощник судьи произвели случайную выборку из общего и запасного списков кандидатов в присяжные заседатели, составляется общий предварительный список кандидатов с указанием их личностных характеристик (фамилия, имя, отчество, адрес регистрации). Следует подчеркнуть тот факт, что фамилии присяжных заседателей вносятся в предварительный список исключительно в том порядке, в котором производилась случайная выборка. Тем присяжным заседателям, которые были включены в список, не позднее чем за семь суток до начала судебного разбирательства вручаются судебные извещения, с требованием во определенное время явиться в суд.

После выполнения вышеуказанных требований, судья приступает к непосредственной подготовке уголовного дела к судебному разбирательству. В частности, в рамках подготовительной части проверяется явка кандидатов в присяжные заседатели. Если в суд явилось менее двадцати кандидатов в 
присяжные заседатели, то судья дает распоряжение о вызове в суд дополнительных кандидатов. После того, как в суд явилось не менее двадцати кандидатов, списки с подменённым указанием явившихся в суд вручаются сторонам, при этом судья разъясняет сторонам их права: заявить мотивированный отвод присяжному заседателю, заявить немотивированный отвод присяжного заседателя, разъясняет и иные права, и последствия их неиспользования.Непосредственно после этого начинается формирование коллегии присяжных заседателей.

Исходя из положений ст. 328 УПК РФ, председательствующий судья произносит перед кандидатами, явившимися в зал судебного заседания вступительное слово, в котором он представляет стороны, непосредственно представляется сам, сообщает общую информацию по рассматриваемому уголовному делу, информирует кандидатов в присяжные заседатели об предполагаемой продолжительности судебного разбирательства по делу, информирует кандидатов в присяжные заседатели относительно задач, которые будут стоять перед ними, информирует кандидатов в присяжные заседатели относительно условий участия их в рассмотрении уголовного дела, информирует кандидатов в присяжные заседатели об обязанностях отвечать максимально правдиво по вопросам которые будут поставлены в рамках рассматриваемого уголовного дела, а также указывает на обязанность кандидатов в присяжные заседатели предоставить информацию о себе и об отношениях с иными участниками уголовного судопроизводства по рассматриваемому делу.

Далее суд переходит к процедуре непосредственного формирования коллегии присяжных заседателей, которая включает в себя рассмотрение самоотводов, мотивированных и немотивированных отводов. Судья, председательствующий в судебном заседании, в-первую очередь опрашивает кандидатов в присяжные заседатели относительно обстоятельств которые могут помешать их участию в рассмотрение конкретного уголовного дела. Любой из кандидатов в присяжные заседатели должен заявить председательствующему судье относительно наличия таких обстоятельств, либо заявить самоотвод. Следует подчеркнуть тот факт, что рассматривая самоотводы и заявления относительно обстоятельств, которые могут помешать участию в уголовном деле присяжного заседателя, судья опрашивает стороны относительно их мнения по поводу заявленных самоотводов и об иных обстоятельств (хотя судья не связан их мнением по данным вопросам).

Те кандидаты в присяжные заседатели, чьи самоотводы были удовлетворены, освобождаются от обязанности участия в судебном разбирательстве по конкретному уголовному делу и удаляются из зала судебного заседания (ч. 6 ст. 328 УПК РФ). На наш взгляд данное положение уголовнопроцессуального закона нуждается в корректировке, т.к. в соответствии со ст. 241 УПК РФ, по общему правилу во всех судах разбирательство уголовных дел открытое, за исключением четко оговоренных случаев, перечь которых содержится в ч. 2 ст. 241 УПК РФ. Таким образом, те лица, которые были исключены из списка кандидатов в присяжные заседатели, при желании, могут остаться в зале судебного заседания и присутствовать на любой стадии судебного рассмотрения уголовного дела (безусловно, если дело слушается в «открытом режиме»). На, этом основании считаем, что в ч. $6 \mathrm{~cm}$. 328 УПК РФ фразу «и удаляются из зала судебного заседания» следует исключить и дополнить часть 
новым предложением следующего содержания: «Дальнейтее их присутствие в зале судебного заседания допускается в соответствии со статьей 241 настоямего Кодекса».

Как показывают проанализированные материалы судебной практики, очень часто присяжные заседатели скрывают информацию относительно своей личности (См. например: приговор Магаданского областного суда от 27 декабря 2012 г.). При этом подчеркнем, что сокрытие такой информации лишает стороньг законных оснований на заявление мотивированных либо немотивированных отводов, что в свою очередь является основанием для дальнейшей отмены приговора по уголовному делу. Приведенный выше пример из практики, к сожалению, не является единичным случаем,из-за сокрытия присяжным заседателем важной информации касающейся своей личности, отменяется достаточно большое количество судебных приговоров. Учитывая этот факт, нами предлагается ввести в КоАП РФ статью, устанавливаюшую административную ответственность за умышленное сокрытие кандидатом в присяжные заседатели сведений относительно своей личности (при условии, что в сокрытых сведениях имеются обстоятельства, которые в соответствии с уголовно-прочессуальным законом являются препятствием для отправления правосудия в качестве присяжного заседателя).

После того, как процедура заявления и удовлетворения самоотводов кандидатов в присяжные заседатели завершается, стороны могут реализовать свое право на заявление мотивированных отводов кандидатов в присяжные заседатели. При этом стороны вправе задать вопросы тем присяжным заседателям, которые остались. После этого стороны передают председательствующему свои мотивированные письменные ходатайства относительно отвода присяжных, при этом в зале судебного заседания они не оглашаются. Данные ходатайства рассматриваются и разрешаются судьей без удаления в совещательную комнату.

Информацию о кандидатах в присяжные заседатели, которые были исключены из предварительного списка, председательствующий судья доводит до сведения сторон. В случае, если после удовлетворения всех самоотводов и мотивированных отводов осталось менее восемнадцати присяжных заседателей, то председательствующий судья дает распоряжение о вызове дополнительных кандидатов. Если же количество кандидатов составляет восемнадцать и более, то председательствующий судья предлагает сторонам, участвующим в рассмотрении уголовного дела заявить немотивированные отводы путем вычеркивания ими из полученного предварительного списка фамилий отводимых кандидатов в присяжные заседатели.

Подчеркнем, что правом использовать отвод присяжному заседателю наделен только подсудимый (его защитник) и государственный обвинитель, причем такой отвод может быть заявлен только два раза каждой стороной.

После того, как рамках подготовки дела к судебному разбирательству были решены вопросы, касающиеся самоотводов и отводов присяжных заседателей, секретарь судебного заседания или помощник судьи формируют список оставшихся граждан-кандидатов в присяжные заседатели, при этом фамилии оставшихся кандидатов включаются в список именно в той последовательности, в которой они были в первоначальном списке.

После завершения данной процедуры, председательствующий судья объявляет результаты проведенного отбора присяжных заседателей (указывая при 
этом основания исключения того или иного кандидата из списка присяжных заседателей), благодарит оставшихся кандидатов в присяжные заседатели. При этом подчеркнем тот факт, что в случае если оставшихся кандидатов в присяжные заседатели останется менее четырнадцати, то необходимое количество лиц вызывается в суд дополнительно по запасному списку, причем в отношении вновь вызванных вопросы об их освобождении от участия в рассмотрении уголовного дела и отводах решаются в общем порядке. По окончании этой деятельности и ее результатам председательствующий оглашает фамилии, имена и отчества присяжных заседателей, занесенные в протокол судебного заседания. При этом первые двенадцать образуют коллегию присяжных заседателей по уголовному делу, а два последних участвуют в рассмотрении уголовного дела в качестве запасных присяжных заседателей.

После того, как формирование коллегии присяжных заседателей считается завершенным, судья предлагает двенадцати основным присяжным заседателям занять их места на специальной скамье присяжных заседателей, которая должна быть отделана от присутствующих в зале судебного заседания, от адвоката, государственного обвинителя. Как правило, скамья присяжных заседателей находится прямо напротив обвиняемого. Что касается двух запасных присяжных заседателей, то они размещаются в специально отведенной зоне, отделенной от основного состава присяжных заседателей. Следует обратить внимание на тот факт, что в случае если в материалах дела содержится информация о государственной, или иной охраняемой законом тайне, то с присяжных заседателей берется соответствующая подписка о неразглашении. В случае, если какой-либо из присяжных заседателей отказывается дать подобную подписку, то он заменяется запасным присяжным заседателем.

Уголовно-процессуальное законодательство предусматривает случай, когда количество выбывших присяжных заседателей может превысить количество запасных. В такой ситуации состоявшееся судебное разбирательство признается недействительным, а председательствующий приступает к отбору присяжных заседателей, в котором могут принимать.участие и присяжные заседатели, освободившиеся в связи с роспуском коллегии.

Таким образом, в заключении можно сделать следующие выводы. Современная система формирования коллегии присяжных заседателей представляет собой действенный и прозрачный механизм, при котором равное воздействие на процессы отбора присяжных представляются как стороне обвинения, так и стороне защиты, в чем на наш взгляд проявляется принцип равноправия и состязательности сторон. Что касается самого механизма формирования коллегии присяжных, то он в наиболее общем виде состоит из следующих частей: вступительного слова председательствующего судьи, опроса кандидатов в присяжные заседатели судьей и сторонами, обсуждения каждого кандидата, отвода кандидатов и собственно образования коллегии присяжных заседателей. 


\section{Литература}

1. Уголовно-процессуальный кодекс Российской Федерации: Федеральный закон от 18.12.2001 № 174-Ф3 (ред. от ред. от 19.12.2016г.) // Собрание законодательства РФ. - 2001. - № 52 (ч. I). - Ст. 4921; Собрание законодательства РФ. - 2016. - № 52 (Часть V). - Ст. 7506.

2. Материал уголовного дела № 1-172/2012 от 27 декабря 2012 г. по делу № 1-172/2012 [Электронный ресурс] // Консультант Плюс: справочные и правовые системы: материалы судебной практики. - Режим доступа: http://base.consultant.ru. - Дата обращения: 18.02.2017г.

3. Моисеева Т.В. Объективная и беспристрастная коллегия присяжных заседателей: общие условия формирования/ Т.В. Моисеева // Журнал российского права. - 2011. — № 11. - С. 79-84.

4. Спирин С.В. Теория и практика формирования состава коллегии присяжных заседателей по уголовному делу...дисс. канд. юрид. наук/ С.В. Спирин. - Самара, 2010. - 177 с.

5. Тисен О.Н. Теоретические и практические проблемы формирования коллегииприсяжных заседателей: Монография/ О.Н. Тисен. - М.: Юрлитинформ, 2010. - 169 с.

6. Чашин А.Н. Суд присяжных в России: учебное пособие/ А.Н. Чашин. М.: Дело и сервис, 2013. - 128 с. 